\title{
Antiviral T-Cell Frequencies in a Healthy Population: Reference Values for Evaluating Antiviral Immune Cell Profiles in Immunocompromised Patients
}

\author{
Friederike C. Schulze Lammers ${ }^{1}$ - Agnes Bonifacius ${ }^{1}$. Sabine Tischer-Zimmermann ${ }^{1}$ - Lilia Goudeva ${ }^{1}$. Jörg Martens ${ }^{1}$. \\ Bernd Lepenies $^{2}$ - Maria von Karpowitz ${ }^{3}$. Gunilla Einecke ${ }^{4}$. Gernot Beutel ${ }^{5}$. Thomas Skripuletz ${ }^{6}$. Rainer Blasczyk ${ }^{1}$. \\ Rita Beier ${ }^{7} \cdot$ Britta Maecker-Kolhoff ${ }^{7} \cdot$ Britta Eiz-Vesper $^{1}$ (D)
}

Received: 29 September 2021 / Accepted: 23 December 2021 / Published online: 6 January 2022

(c) The Author(s) 2022

\begin{abstract}
Viral infections and reactivations are major causes of morbidity and mortality after hematopoietic stem cell (HSCT) and solid organ transplantation (SOT) as well as in patients with immunodeficiencies. Latent herpesviruses (e.g., cytomegalovirus, Epstein-Barr virus, and human herpesvirus 6), lytic viruses (e.g., adenovirus), and polyomaviruses (e.g., BK virus, JC virus) can cause severe complications. Antiviral drugs form the mainstay of treatment for viral infections and reactivations after transplantation, but they have side effects and cannot achieve complete viral clearance without prior reconstitution of functional antiviral T-cell immunity. The aim of this study was to establish normal ranges for virus-specific T-cell (VST) frequencies in healthy donors. Such data are needed for better interpretation of VST frequencies observed in immunocompromised patients. Therefore, we measured the frequencies of VSTs against 23 viral protein-derived peptide pools from 11 clinically relevant human viruses in blood from healthy donors $(n=151)$. Specifically, we determined the VST frequencies by interferon-gamma enzyme-linked immunospot assay and classified their distribution according to age and gender to allow for a more specific evaluation and prediction of antiviral immune responses. The reference values established here provide an invaluable tool for immune response evaluation, intensity of therapeutic drugs and treatment decision-making in immunosuppressed patients. This data should make an important contribution to improving the assessment of immune responses in immunocompromised patients.
\end{abstract}

Keywords Antiviral T-cell repertoire · Virus-specific T cells · Adaptive immunity · Immunosuppression · Transplantation · Cellular therapy $\cdot$ Cellular immunity

Friederike C. Schulze Lammers and Agnes Bonifacius contributed equally to this work.

Britta Eiz-Vesper

eiz-vesper.britta@mh-hannover.de

1 Institute of Transfusion Medicine and Transplant Engineering, Hannover Medical School, Carl-Neuberg-Str. 1, 30625 Hannover, DE, Germany

2 Institute for Immunology \& Research Center for Emerging Infections and Zoonoses, University of Veterinary Medicine Hannover, Hannover, DE, Germany

3 Institute for Biostatistics, Hannover Medical School, Hannover, DE, Germany

\section{Introduction}

Following hematopoietic stem cell (HSCT) and solid organ transplantation (SOT), immunosuppressive therapy is administered to prevent graft rejection and graft-versus-host

4 Department of Nephrology, Hannover Medical School, Hannover, DE, Germany

5 Department of Hematology, Hemostasis, Oncology and Stem Cell Transplantation, Hannover Medical School, Hannover, DE, Germany

6 Department of Neurology, Hannover Medical School, Hannover, DE, Germany

7 Department of Pediatric Hematology and Oncology, Hannover Medical School, Hannover, DE, Germany 
disease (GvHD). Prophylactic regimens transiently lead to strong immunosuppression, mainly, by decreasing $\mathrm{CD}^{+}$ T-cell numbers [1]. Consequently, the risk of life-threatening bacterial, fungal, and viral infections as well as recurrent viral reactivation increases. Additionally, lymphopenia in the regeneration phase after HSCT enhances the pathogenassociated morbidity and mortality. Up to $22 \%$ and $53 \%$ of overall mortality after HSCT and SOT, respectively, are associated with infections resulting from a lack of specific T-cell immunity [2-4]. Individuals with congenital primary or secondary immunodeficiencies are even more susceptible to infectious complications, which are among the leading causes of death [5-7].

The main viral pathogens causing infection-related deaths in patients with immunodeficiency or after transplantation are endogenous herpesviruses such as cytomegalovirus (CMV), Epstein-Barr virus (EBV), and human herpesvirus 6 (HHV6); lytic viruses like adenovirus (ADV); as well as polyomaviruses such as the $\mathrm{BK}(\mathrm{BKV})$ and $\mathrm{JC}$ virus (JCV) [7-14]. CMV reactivation observed in $40-65 \%$ of CMVseropositive recipients after HSCT is associated with a higher risk of mortality [15-17]. Incidence rates of EBV reactivation and post-transplant lymphoproliferative disease (PTLD) vary from 0.1 to $63 \%$, depending on the type of transplant [17-20]. In patients with immunodeficiencies, especially severe combined immunodeficiencies, fatality rates from severe and recurrent pulmonary ADV infections as well as disseminated disease have been reported to be up to 55\% [1, 21]. High-level HHV6 reactivation after allogeneic HSCT has been described in 30-50\% of recipients [22, 23]. BKV and JCV viremia occur in $54 \%$ and $25 \%$ of HSCT recipients, respectively, JCV viruria in 3.8-40\% of kidney transplant patients, and BKV-induced nephropathy in 5.3\% of the patients [17, 24, 25]. JCV reactivation in transplant and non-transplant patients can result in life-threatening progressive multifocal leukoencephalopathy (PML), with mortality rates of up to $71 \%$ [26-28]. Other herpesviruses like herpes simplex virus type 1 (HSV1), herpes simplex virus type 2 (HSV2), and varicella-zoster virus (VZV), along with respiratory RNA viruses such as influenza A virus (IAV) and human respiratory syncytial virus (RSV), expose immunocompromised individuals to a constant risk of severe and potentially life-threatening complications [29-32].

Over the last decades, advances in antiviral drug therapy and prophylactic and pre-emptive antiviral treatment strategies have decreased infectious complications in immunocompromised patients. However, they are associated with toxic side effects and ineffective in case of drug resistances. Moreover, due to insufficient reconstitution of cellular immunity, viral infections can only be controlled but not completely eliminated $[16,33,34]$. A major clinical challenge remains the complex interplay between immunosuppressive treatment and the maintenance or establishment of antiviral immunity [8]. Therefore, clinicians must carefully balance the risks of graft rejection or GvHD on the one side and the maintenance of protective immunity on the other.

Currently, information about virus-specific T-cell (VST) frequencies required for virus control and clearance is scarce and empirical data on protective pathogen-specific T-cell numbers in blood are highly desirable. Individualized antiviral treatment strategies require knowledge about VST frequencies since it helps clinicians assess the effects of modalities such as antiviral drug therapy, and weigh the opportunity or need for reduction of immunosuppression or adoptive T-cell transfer (AT) [35-37]. If the VST frequencies of an immunosuppressed patient are within normal ranges of healthy donors, antiviral drug therapy presents a successful strategy. With VST frequencies below average, cellular therapies, such as AT, offer a promising approach. Reference ranges will help clinicians to predict responses to AT $[2,38,39]$.

The aim of this study was to provide data on VST frequencies in a population of healthy donors $(n=151)$ as an aid to therapeutic decision-making in immunocompromised patients and patients with immune disorders. Antiviral T cells against 11 clinically highly relevant viruses were determined by interferon-gamma (IFN- $\gamma$ ) enzyme-linked immunospot (ELISpot) and characterized regarding frequency, phenotype, age, and gender. Moreover, ELISpot data were correlated to serological testing routinely performed for 7 of the 11 viruses. All donors were seropositive for at least four viruses, and the spectrum of antiviral immunity increased with age. Overall, VST frequencies were higher for DNA and persistent viruses (CMV, EBV), lower for RNA viruses (RSV, IAV), and lowest for BKV and JCV. The reference values established in this study give clinicians a valuable tool for interpreting a patient's specific antiviral T-cell profile, and for estimating the need for and type of further therapeutic interventions, which could potentially be a breakthrough in the evaluation of immune status [40-43].

\section{Methods}

\section{Study Population}

VST frequencies were determined using residual blood samples from platelet apheresis disposable kits used for routine platelet collection from healthy blood donors of the Institute of Transfusion Medicine and Transplant Engineering (MHH). Written informed consent was obtained from all donors (ethics committee vote 3639-2017). Peripheral blood mononuclear cells (PBMCs) were isolated by discontinuous gradient centrifugation and resuspended in T-cell culture medium (RPMI 1640 (Lonza, Vervies) with 10\% human AB serum (c.c.pro)). Whole blood and serum samples were 
collected on the same day for flow cytometric and serological analysis.

\section{Flow Cytometry}

Whole blood samples were transferred into BD Trucount ${ }^{\mathrm{TM}}$ tubes and extracellularly stained (Tab.S1), followed by erythrocyte lysis (Lysing Solution, BD Biosciences). For analysis of IFN- $\gamma$ ELISpot assay, $1 \times 10^{6}$ isolated PBMCs were extracellularly stained (Tab.S2) and washed. Samples were acquired on a FACSCanto ${ }^{\mathrm{TM}} 10 \mathrm{c}$ cytometer (BD Biosciences), and data were analyzed with BD FACS$\mathrm{Diva}^{\mathrm{TM}}$ Software v8.0. Gating strategies for $\mathrm{CD}^{+}, \mathrm{CD}^{+}$, and $\mathrm{CD}^{+} \mathrm{T}$ cells as well as for memory T-cell phenotypes are shown in Fig.S1A + B.

\section{IFN- $\boldsymbol{E}$ ELISpot}

IFN- $\gamma$ ELISpot assay was performed as described previously $[44,45]$; details are provided in supplementary information (Methods, Tab.S3).

\section{Serology}

CMV-specific antibodies were detected using CMV-IgG assay (Abbott Diagnostic). Additionally, antibodies against CMV, EBV, and HSV1/2 (recomLine, Mikrogen) as well as ADV, VZV, RSV, and IAV (NovaLisa, NovaTec Immundiagnostica $\mathrm{GmbH}$ ) were analyzed.

\section{Data Analysis}

Data were analyzed using Microsoft Excel 2010/2016 (Microsoft Corporation) and displayed using Flow $\mathrm{Jo}^{\mathrm{TM}} \mathrm{v} 10$ (FlowJo ${ }^{\text {TM }}$ LLC, BD Biosciences) and GraphPad Prism v8.2 (GraphPad Software).

\section{Results}

\section{Donor Cohort}

A total of 151 healthy donors ( 87 male, 64 female) with an average age of 42 years (19-67 years) were included in this study (Fig.S1C). The population was divided into four groups according to age and gender: males 40 years of age or younger $(n=40)$, males over the age of $40(n=47)$, females 40 years of age or younger $(n=30)$, and females over the age of $40(n=34)$. Frequencies of naïve T cells $\left(\mathrm{T}_{\mathrm{N}}: \mathrm{CD} 45 \mathrm{RA}^{+} \mathrm{CD} 6 \mathrm{~L}^{+}\right)$were higher in younger donors, while central memory $\mathrm{T}$ cells $\left(\mathrm{T}_{\mathrm{CM}}\right.$ : $\left.\mathrm{CD} 45 \mathrm{RA}^{-} \mathrm{CD}^{-} \mathrm{L}^{+}\right)$ were more frequent among older donors (Fig.S1D). Slightly higher frequencies of effector memory $\mathrm{T}$ cells $\left(\mathrm{T}_{\mathrm{EM}}\right.$ :
$\mathrm{CD} 45 \mathrm{RA}^{-} \mathrm{CD}^{-} 2 \mathrm{~L}^{-}$) were observed in males than in females. Frequencies of $\mathrm{CD}^{+} \mathrm{T}$ effector memory cells re-expressing CD45RA ( $\left.\mathrm{T}_{\mathrm{EMRA}}: \mathrm{CD} 4 \mathrm{RA}^{+} \mathrm{CD} 6 \mathrm{~L}^{-}\right)$were lower than $\mathrm{CD} 8{ }^{+} \mathrm{T}_{\mathrm{EMRA}}$ in all groups.

Routinely applied serological testing was performed to determine the serostatus for CMV, EBV, HSV, VZV, ADV, RSV, and IAV (Tab.S4). Initially, 76 donors (50.3\%) were classified as CMV-seropositive by routine anti-CMV-IgG ELISA testing, which was not confirmed in 10 of these donors by immunoblot [44]. Since follow-up samples confirmed the negative serology, further analysis was based on immunoblot results. Interestingly, within CMV- and HSVseropositive subgroups, the proportion of EBV-seropositive donors (95.5\% and 96.9\%) was increased compared with the overall cohort. Similarly, the proportion of HSV-seropositive donors within CMV-seropositive donors (75.8\%) was increased compared with the overall cohort. All donors were seropositive for at least four of the seven tested viruses and the number of positive serological tests increased with age (Tab.S5).

\section{Antiviral T-Cell Frequencies}

VST frequencies against 23 peptide pools derived from 11 viruses were determined by IFN- $\gamma$ ELISpot and normalized to $\mathrm{CD}^{+} \mathrm{T}$-cell numbers and used to classify donors as non-, low, intermediate, and high responders (Fig. 1). Antiviral T-cell frequencies were analyzed regarding age and gender distribution, $\mathrm{CD}^{+} \mathrm{T}$-cell frequencies, and the number of functionally active VSTs per microliter blood (Figs.S1C+D, S2-S11). Reference values for evaluation of immune responses in patients were generated by calculating mean $\pm \mathrm{SD}$, minimum, maximum, $25 \%$ and $75 \%$ percentiles, median, and limits of the $95 \%$ confidence interval (Tables 1 and S6, Figs. 1A and 2).

\section{Herpesviruses}

All $C M V$-seropositive donors had T-cell responses against phosphoprotein 65 (pp65). CMV_pp65-specific T-cell frequencies were higher than those for immediate early protein-1 (IE-1) (Figs. 1, 2, S2, Tables 1 and S6). In CMVseronegative donors, no CMV-specific $\mathrm{T}$ cells were detected. Frequencies of CMV-specific $\mathrm{T}$ cells slightly increased with age in males, but not in females. The frequency of memory $\mathrm{T}$ cells was markedly higher in CMV-seropositive than in CMV-seronegative donors and mainly consisted of $\mathrm{T}_{\mathrm{EMRA}}$ (Tab.S7). Interestingly, the percentage of total $\mathrm{CD}^{+} \mathrm{T}_{\mathrm{EMRA}}$ within the different responder groups was larger in high responders than in intermediate and low responders.

All $E B V$-seropositive donors had detectable EBV-specific $\mathrm{T}$ cells against at least one of the peptide pools Epstein-Barr nuclear antigen-1 (EBNA-1), Consensus, latent membrane 

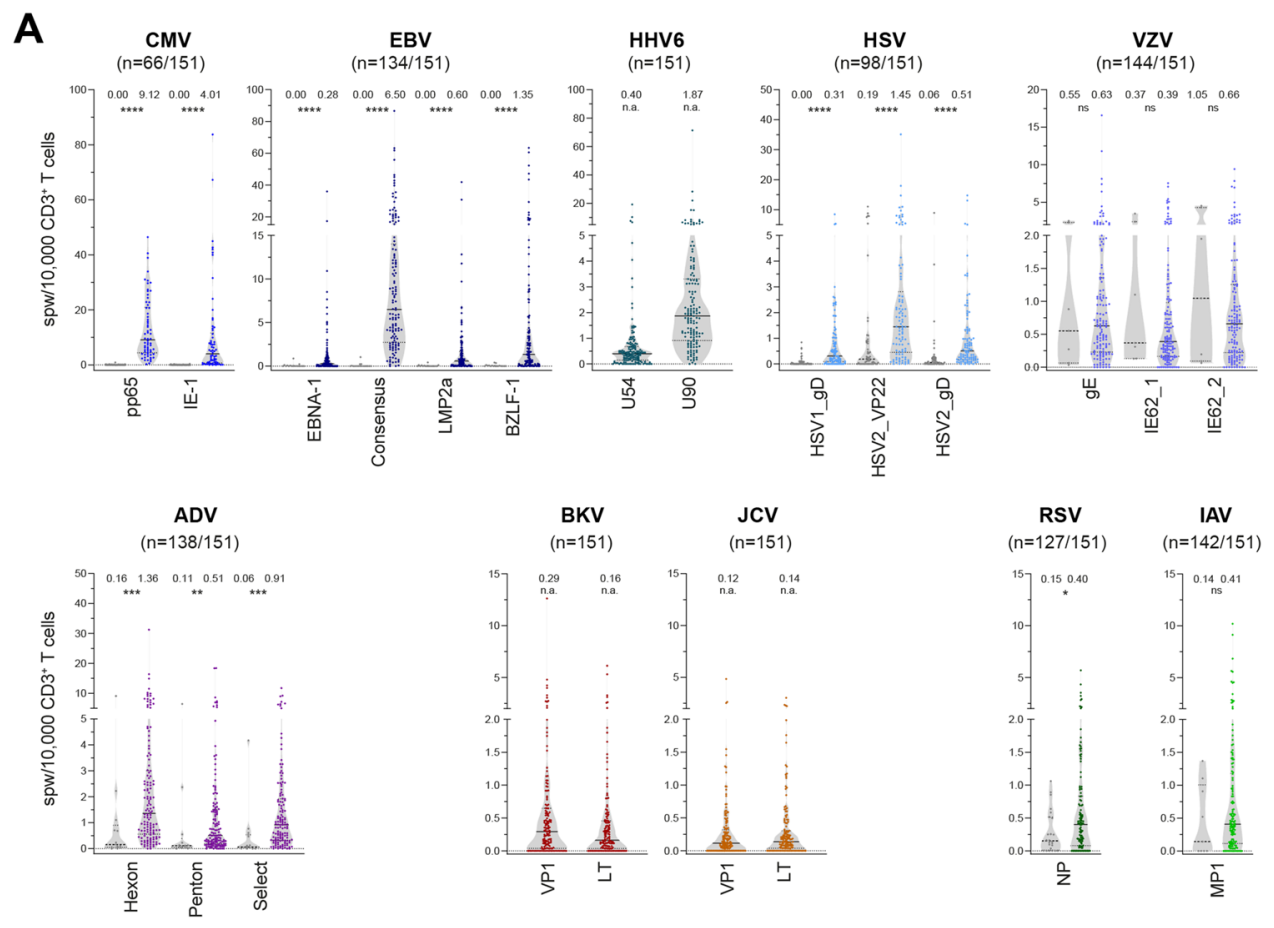

B

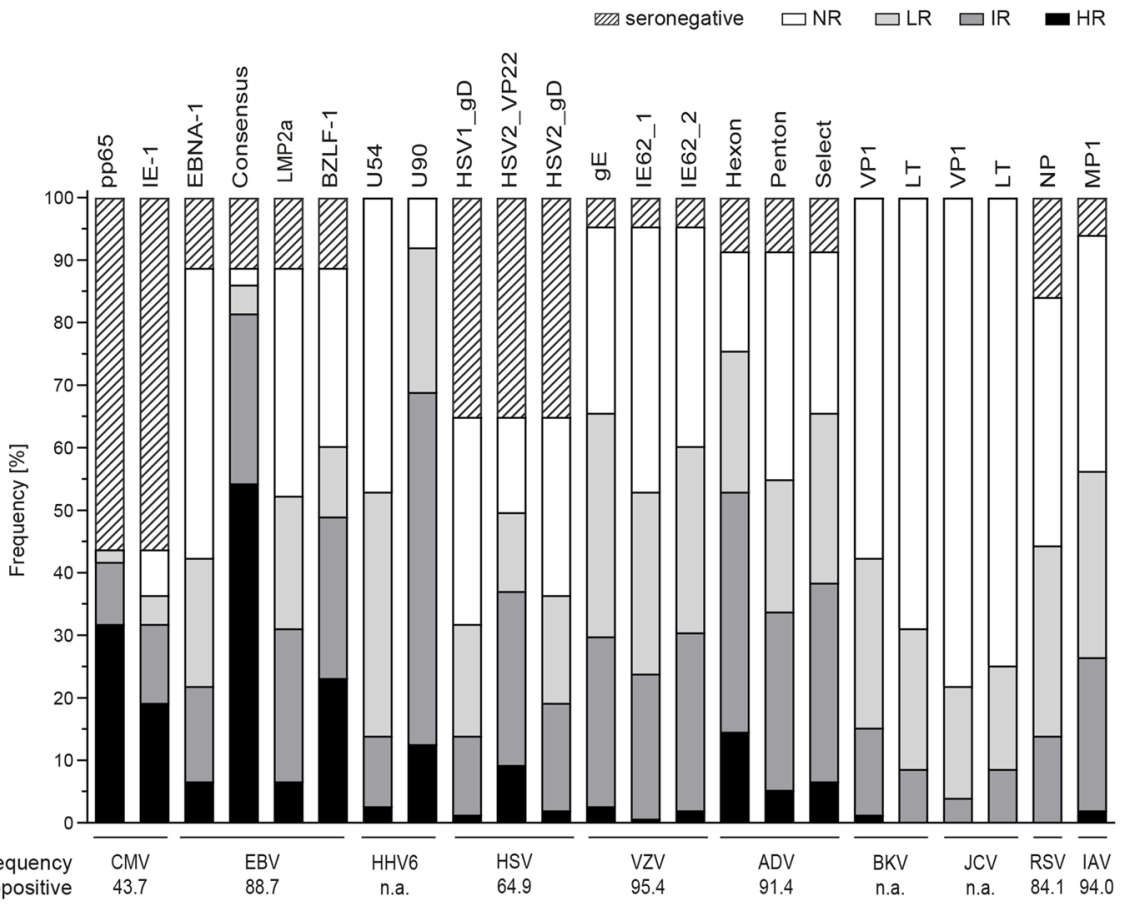

Fig. 1 Antiviral T-cell frequencies in seropositive donors. Frequencies of antiviral T-cells were determined in a large cohort of healthy donors $(n=151)$ by ELISpot assay. A Antiviral T-cell frequencies normalized to $\mathrm{CD}^{+}$T-cell frequencies within PBMCs and expressed as spots per $10,000 \mathrm{CD}^{+} \mathrm{T}$ cells in seropositive and seronegative donors (colored and gray symbols, respectively), unless otherwise stated. Data are shown as violin plots; each symbol represents one donor. Horizontal lines represent median values, and dotted lines the $25 \%$ and $75 \%$ percentiles, respectively. The number above each data set indicates the median. Asterisks show significant difference to values obtained from seronegative donors (Mann-Whitney test). B Comparative overview of frequency of donors with positive serology for which virus-specific $\mathrm{T}$ cells for the respective antigens were detected (total number of donors: $n=151$ ). Donors were grouped according to the number of spots per well (spw) generated in response to each peptide pool as follows: high responders (HR, $\geq 50$ spw or $47 \mathrm{spw}+2 \times$ negative control (NC)), intermediate responders (IR, $\geq 10$ spw or $7 \mathrm{spw}+2 \times \mathrm{xNC})$, low responders $(\mathrm{LR}, \geq 3$ spw or $2 \mathrm{xNC}$ ), and non-responders (NR, $<3$ spw or $2 \mathrm{xNC}$ ). CMV cytomegalovirus, EBV Epstein-Barr virus, HHV6 human herpesvirus 6, HSV herpes simplex virus, VZV varicella-zoster virus, ADV adenovirus, $\mathrm{BKV}$ BK polyomavirus, JCV JC polyomavirus, RSV respiratory syncytial virus, IAV influenza A virus. $* p<0.05$, ** $p<0.01$, *** $p<0.001$, **** $p<0.0001$, ns not significant, n.a. not applicable 
Table 1 Reference values based on serological results and frequencies of virus-specific T-cells in healthy donors $(n=151)$. See also Tab. S3

\begin{tabular}{|c|c|c|c|c|c|c|c|c|c|c|}
\hline $\begin{array}{l}\text { Virus } \\
\text { Seropositive out } \\
\text { of total } n(\%)\end{array}$ & Antigen & Min & $25 \%$ percentile & Median & $75 \%$ percentile & Max & Mean & SD & $\begin{array}{l}\text { Lower } 95 \% \\
\text { CI of median }\end{array}$ & $\begin{array}{l}\text { Upper } \\
95 \% \text { CI of } \\
\text { median }\end{array}$ \\
\hline \multirow{2}{*}{$\begin{array}{l}\text { CMV } \\
66(43.7)\end{array}$} & pp65 & 0.25 & 4.41 & 9.12 & 20.97 & 46.42 & 13.17 & 11.18 & 10.43 & 15.92 \\
\hline & IE-1 & 0.00 & 0.68 & 4.01 & 11.56 & 83.76 & 10.32 & 16.46 & 6.28 & 14.37 \\
\hline \multirow{4}{*}{$\begin{array}{l}\text { EBV } \\
134(88.7)\end{array}$} & EBNA-1 & 0.00 & 0.03 & 0.28 & 0.96 & 35.90 & 1.31 & 3.75 & 0.67 & 1.95 \\
\hline & Consensus & 0.00 & 2.73 & 6.50 & 14.01 & 86.61 & 11.69 & 14.22 & 9.26 & 14.12 \\
\hline & LMP2a & 0.00 & 0.08 & 0.60 & 1.70 & 41.83 & 1.83 & 4.80 & 1.01 & 2.65 \\
\hline & BZLF-1 & 0.00 & 0.21 & 1.35 & 4.19 & 63.34 & 5.38 & 11.04 & 3.50 & 7.27 \\
\hline \multirow[t]{2}{*}{ HHV6 } & U54 & 0.00 & 0.15 & 0.40 & 0.68 & 19.25 & 0.82 & 1.99 & 0.50 & 1.14 \\
\hline & U90 & 0.00 & 0.91 & 1.87 & 3.31 & 71.34 & 3.20 & 6.61 & 2.14 & 4.27 \\
\hline \multirow{3}{*}{$\begin{array}{l}\text { HSV } \\
98(64.9)\end{array}$} & HSV1_gD & 0.00 & 0.09 & 0.31 & 1.02 & 8.47 & 0.80 & 1.26 & 0.55 & 1.05 \\
\hline & HSV2_VP22 & 0.00 & 0.46 & 1.45 & 2.81 & 35.12 & 2.82 & 4.60 & 1.89 & 3.74 \\
\hline & HSV2_gD & 0.00 & 0.18 & 0.51 & 1.28 & 14.78 & 1.16 & 2.15 & 0.73 & 1.59 \\
\hline \multirow{3}{*}{$\begin{array}{l}\text { VZV } \\
144(95.4)\end{array}$} & $\mathrm{gE}$ & 0.00 & 0.23 & 0.63 & 1.36 & 16.58 & 1.20 & 2.02 & 0.86 & 1.53 \\
\hline & IE62_1 & 0.00 & 0.16 & 0.39 & 0.98 & 7.54 & 0.90 & 1.34 & 0.68 & 1.12 \\
\hline & IE62_2 & 0.00 & 0.22 & 0.66 & 1.26 & 9.43 & 1.08 & 1.48 & 0.83 & 1.32 \\
\hline \multirow{3}{*}{$\begin{array}{l}\text { ADV } \\
138(91.4)\end{array}$} & Hexon & 0.00 & 0.56 & 1.36 & 3.01 & 31.23 & 2.67 & 3.86 & 2.02 & 3.32 \\
\hline & Penton & 0.00 & 0.19 & 0.51 & 1.50 & 18.40 & 1.40 & 2.62 & 0.96 & 1.84 \\
\hline & Select & 0.00 & 0.32 & 0.91 & 1.92 & 11.77 & 1.52 & 1.94 & 1.19 & 1.84 \\
\hline \multirow[t]{2}{*}{ BKV } & VP1 & 0.00 & 0.04 & 0.29 & 0.65 & 12.62 & 0.64 & 1.30 & 0.43 & 0.85 \\
\hline & $\mathrm{LT}$ & 0.00 & 0.04 & 0.16 & 0.46 & 6.14 & 0.44 & 0.85 & 0.31 & 0.58 \\
\hline \multirow[t]{2}{*}{ JCV } & VP1 & 0.00 & 0.00 & 0.12 & 0.32 & 4.86 & 0.29 & 0.55 & 0.20 & 0.38 \\
\hline & $\mathrm{LT}$ & 0.00 & 0.04 & 0.14 & 0.31 & 3.04 & 0.32 & 0.51 & 0.24 & 0.40 \\
\hline $\begin{array}{l}\text { RSV } \\
127(84.1)\end{array}$ & NP & 0.00 & 0.08 & 0.40 & 0.83 & 5.69 & 0.67 & 0.91 & 0.51 & 0.83 \\
\hline $\begin{array}{l}\text { IAV } \\
142(94.0)\end{array}$ & MP1 & 0.00 & 0.11 & 0.41 & 1.18 & 10.20 & 0.96 & 1.58 & 0.70 & 1.22 \\
\hline
\end{tabular}

$C M V$ cytomegalovirus, $E B V$ Epstein-Barr virus, $H H V 6$ human herpesvirus 6, $H S V$ herpes simplex virus, $V Z V$ varicella-zoster virus, $A D V$ adenovirus, $B K V \mathrm{BK}$ polyomavirus, $J C V \mathrm{JC}$ polyomavirus, $R S V$ respiratory syncytial virus, $I A V$ influenza A virus

protein 2a (LMP2a), and BamHI Z fragment leftward open reading frame 1 (BZLF-1) (Figs. 1, 2, S3, Tables 1 and S6). The remaining EBV-seronegative donors had no detectable EBV-specific T cells. Moreover, $97.0 \%$ of the EBVseropositive donors possessed EBV_Consensus-specific T cells, while less donors responded to the other tested antigens. Most high responders were found for EBV_Consensus (63.1\%) and EBV_BZLF-1 (38.5\%). Likewise, antigenspecific T cells to EBV_Consensus were most frequent, and their frequency slightly increased with age regardless of gender. Moreover, LMP2a-specific T-cell frequencies increased significantly with age in males. EBV_Consensus low and non-responders had noticeably increased frequencies of $\mathrm{CD} 8^{+} \mathrm{T}_{\mathrm{N}}$ cells accompanied by lower frequencies of $\mathrm{CD} 8^{+} \mathrm{T}_{\mathrm{CM}}$ compared to high and intermediate responders (Tab.S7). Accordingly, EBV_LMP2a intermediate, low, and non-responders had higher frequencies of $\mathrm{CD}^{+} \mathrm{T}_{\mathrm{N}}$ than high responders. $T_{N}$ frequencies generally decreased from non- to high responders, while $\mathrm{T}_{\mathrm{CM}}$ frequencies increased.
HHV6_U90-specific T cells were detected in 139/151 donors $(92.1 \%)$, most $(61.2 \%)$ of whom were intermediate responders, while HHV6_U54-specific T cells were detected in only 80/151 donors (53.0\%), who were mostly low responders $(n=59 / 80,73.8 \%)$ (Figs. 1, 2, S4, Tables 1 and S6). In line with that, the frequency of HHV6_U54-specific T cells was markedly lower than that of HHV6_U90-specific $\mathrm{T}$ cells. Younger and older men had comparable HHV6specific T-cell frequencies, while HHV6_U90-specific T-cell frequencies marginally decreased with age in women. Both intermediate and high responders had lower frequencies of $\mathrm{T}_{\mathrm{N}}$ and higher frequencies of $\mathrm{T}_{\mathrm{EMRA}}$ than low and nonresponders (Tab.S7).

Among the $53 \mathrm{HSV}$-seronegative donors (35.1\%), 21 donors (39.6\%) had HSV-specific T cells. Moreover, among the 98 donors $(64.9 \%)$ classified as HSVseropositive, no HSV-specific T cells could be detected in nine donors $(9.18 \%)$. Only HSV-seropositive donors were included in T-cell response analysis (Figs. 1, 2, S5, 
Fig. 2 Reference values for males (m) aged $\leq 40$ and $>40$, and females (f) aged $\leq 40$ and $\mathrm{f}>40$. Antiviral T-cell frequencies in $n=151$ healthy donors, normalized to $\mathrm{CD}^{+} \mathrm{T}$-cell frequencies within PBMCs and expressed as spots per 10,000 $\mathrm{CD}^{+} \mathrm{T}$ cells, as measured in all (HHV6, BKV, JCV) or seropositive donors (CMV, EBV, HSV, VZV, ADV, RSV, IAV) (see also Fig. 1). Symbols represent median values, and vertical lines the $25 \%$ and $95 \%$ percentiles. See also Tab. S3. CMV cytomegalovirus, EBV Epstein-Barr virus, HHV6 human herpesvirus 6, HSV herpes simplex virus, VZV varicella-zoster virus, $\mathrm{ADV}$ adenovirus, BKV BK polyomavirus, JCV JC polyomavirus, RSV respiratory syncytial virus, IAV influenza A virus

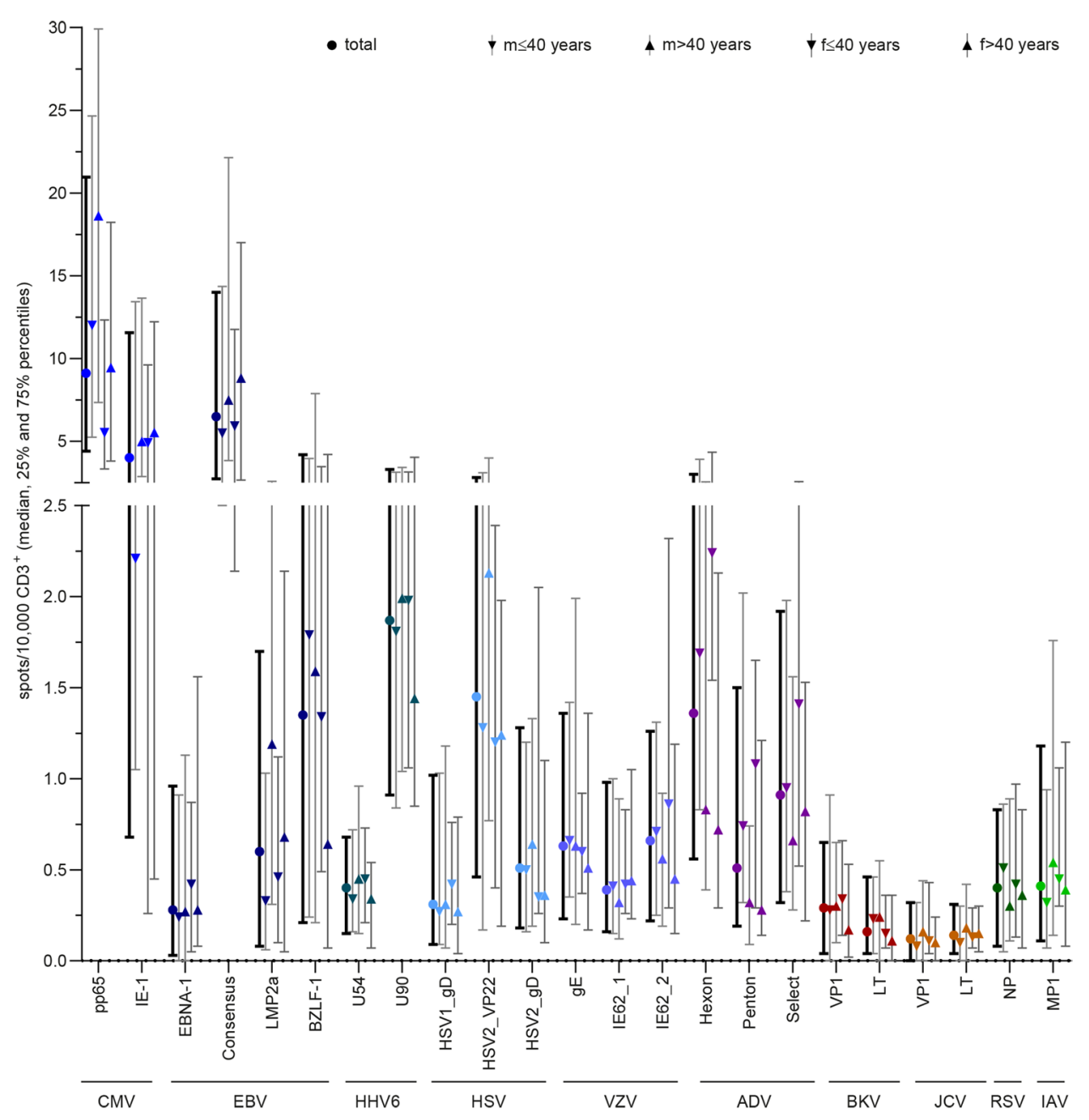

Tables 1 and S6). The highest response rate was observed for HSV2 tegument protein VP22 (VP22; 76.5\%), followed by HSV2 envelope glycoprotein D (gD) $(56.1 \%)$ and HSV1_gD (49.0\%). In line with that, high responders were the most frequent kind of HSV2_VP22 responders (18.7\%). Highest frequencies of HSV-specific T cells were observed for HSV2_VP22, followed by HSV2_gD and HSV1_gD. In male donors, HSV2_VP22-specific T-cell frequencies slightly increased with age. High responders had markedly higher frequencies of $\mathrm{T}_{\mathrm{EMRA}}$ than the other responder groups (Tab.S7).

A large fraction of donors was $V Z V$-seropositive ( $n=144 / 151,95.4 \%$; Fig. 1B). In three donors identified as VZV-seronegative, VZV-specific $\mathrm{T}$ cells were detected $(n=3 / 7 ; 42.9 \%)$. Only VZV-seropositive donors were included in T-cell response analysis (Figs. 1, 2, S6, Tables 1 and S6). A large proportion of VZV-seropositive donors did not have detectable VZV-specific T cells (87.5\%). VZV envelope glycoprotein $\mathrm{E}(\mathrm{gE})$ elicited the highest responder rate $(68.8 \%)$. Most donors were classified as intermediate or low responders. Overall, responder group distributions were comparable for all three peptide pools, as were frequencies of VZV-specific T cells. No distinct differences were observed in relation to age and gender distribution. Most intermediate responders had lower frequencies of $T_{N}$ than low and non-responders (Tab.S7).

\section{Adenovirus}

A total of 138 donors (91.4\%) were tested $A D V$-seropositive by ELISA covering ADV type 2 . Fifteen of these individuals $(10.9 \%)$ showed no response to any of the ADV peptide pools (ADV5_Hexon, ADV5_Penton, ADV2/5_Select), while ADV-specific T cells were detected in four ADVseronegative donors $(30.8 \%)$. These were mainly reactive against ADV5_Hexon and ADV5_Penton. Only seropositive donors were included in T-cell response analysis (Figs. 1, 2, S7, Tables 1 and S6). Most ADV-specific T cells were found to be specific for ADV5_Hexon (82.6\%), followed by ADV2/5_Select (71.7\%) and ADV5_Penton (60.1\%). Likewise, most high responders were found for ADV5_Hexon (19.3\%), and the highest ADV-specific T-cell frequencies 
were found for ADV5_Hexon. ADV_Penton- and ADV_ Hexon-specific T-cell frequencies decreased with age in males and females, respectively. The four responder groups had comparable T-cell phenotype distributions (Tab.S7). However, ADV5_Penton high responders had less $C D 8^{+} \mathrm{T}_{\mathrm{N}}$ and more $\mathrm{T}_{\mathrm{EM}}$ than intermediate, low, and non-responders.

\section{Polyomaviruses}

Sixty-four (42.4\%) donors responded to $B K V \_$major capsid protein (VP1) and 47 (31.1\%) responded to BKV large T antigen (LT), including only $2 / 64$ (3.13\%) high responders to BKV_VP1 and no high responders to BKV_LT (Figs. 1, 2, S8, Tables 1 and S6). BKV_VP1-specific T-cell frequencies were higher than BKV_LT-specific T-cell frequencies. Females had slightly lower frequencies of BKV_LT-specific $\mathrm{T}$ cells than males, and their overall BKV-specific T-cell frequencies tend to decrease with age. Low and non-responders had lower numbers of $\mathrm{T}_{\mathrm{EMRA}}$ and higher frequencies of $\mathrm{T}_{\mathrm{CM}}$ than intermediate responders (Tab.S7).

None of the $33 J C V_{-}$VP1 $(21.9 \%)$ or 38 JCV_LT responders (25.2\%) were high responders (Figs. 1, 2, S9, Tables 1 and S6). Furthermore, JCV had the lowest number of responders and lowest VST frequencies of all tested viruses. JCV-specific T-cell frequencies appear to be highest in older males. Interestingly, JCV_VP1 intermediate responders had markedly increased frequencies of $\mathrm{T}_{\mathrm{EMRA}}$ cells compared to non- and low responders, while JCV_LT intermediate responders had only slightly higher percentages of $\mathrm{CD}^{+} \mathrm{T}_{\mathrm{EMRA}}$ than non- and low responders (Tab.S7).

\section{RNA Viruses}

By ELISA, 127/151 donors (84.1\%) were classified as $R S V$ seropositive; RSV-specific T cells were detected in 8 (33.3\%) RSV-seronegative donors. Only RSV-seropositive donors were included in T-cell analysis (Figs. 1, 2, S10, Tables 1 and S6). Most RSV-seropositive donors had little or no detectable specific T-cell response against RSV nucleoprotein (NP): $47.2 \%$ were non- and $36.2 \%$ low responders. RSVspecific T-cell frequencies marginally decreased with age. Interestingly, intermediate responders had slightly higher fractions of $T_{\mathrm{CM}}$ and $T_{\mathrm{EMRA}}$ than low and non-responders (Tab.S7).

One hundred forty-two of 151 donors (94.0\%) were identified as $I A V$-seropositive by ELISA. IAV-specific T cells against IAV matrix protein 1 (MP1) were detected in 2/9 (22.2\%) IAV-seronegative donors. Only IAV-seropositive donors were included in T-cell evaluation (Figs. 1, 2, S11, Tables 1 and S6). T cells were detected in 59.9\% of seropositive donors, who were mainly low $(31.7 \%)$ and intermediate responders (26.1\%). IAV-specific T-cell frequencies slightly increased with age in males. High responders $(2.11 \%)$ had markedly lower frequencies of $T_{\mathrm{N}}$ and higher frequencies of $T_{\mathrm{CM}}$ (Tab.S7).

\section{Summary and Correlations of Antiviral T Cells}

In the total cohort, a small fraction of donors had $\mathrm{T}$ cells against $\mathrm{CMV}, \mathrm{BKV}$, and JCV while more donors responded to EBV, ADV, HHV6, and VZV (Fig. 1B). All CMV-seropositive donors had T-cell responses to CMV_pp65. For the remaining viruses tested, no VSTs were detectable in a large fraction of seropositive donors except EBV (Consensus; 97.0\%). Furthermore, most donors had $\mathrm{T}$ cells against HHV6 (U90; 92.1\%). CMV- and EBV-specific T-cell frequencies appeared to increase with age, while ADV-specific T-cell frequencies decreased, regardless of gender (Fig. 2). Figure 3 shows the numbers of donors with antiviral T cells against each viral antigen in parallel. Interestingly, few donors had VSTs against both BKV peptide pools $(n=40 / 71$ responders; $56.3 \%$ ). This was even more pronounced for JCV ( $n=17 / 54$ responders; $31.5 \%)$. Despite high sequence homology, considerable differences in responder rates presented for BKV and JCV. However, 28/64 (43.8\%) BKV VP1 responders also responded to JCV_VP1, and 25/47 (53.2\%) BKV_LT responders also responded to JCV_LT. While for some viruses, serological testing was not in line with VST frequencies, the previously described serological correlations between CMV, EBV, and HSV were partly reflected at the T-cell level.

\section{Discussion}

Immunocompromised HSCT and SOT recipients and individuals with congenital primary or secondary immunodeficiencies present a high burden of mortality due to lifethreatening bacterial, fungal, and viral infections as well as recurrent viral reactivations $[1,5,7]$. Although antiviral drug treatments have advanced over the years, they are still associated with toxic side effects. In the absence of functional VSTs, they can only control but not completely eliminate viruses [16, 33, 34]. Antiviral T-cell frequencies determine whether treatment (e.g., antiviral drug therapy, reduction of immunosuppression, or AT) is needed [35-37]. This study aimed to establish reference values for antiviral T-cell frequencies against 11 clinically relevant human viruses in healthy donors. These data should help to improve the prevention and treatment of viral complications, leading to better outcomes in HSCT and SOT recipients and patients with immune disorders.

In the transplant setting, determination of infectious disease markers for viruses mainly includes the CMV and EBV serostatus of donor and recipient. Donor seropositivity provides an opportunity for transfer of antigen-specific $\mathrm{T}$ 


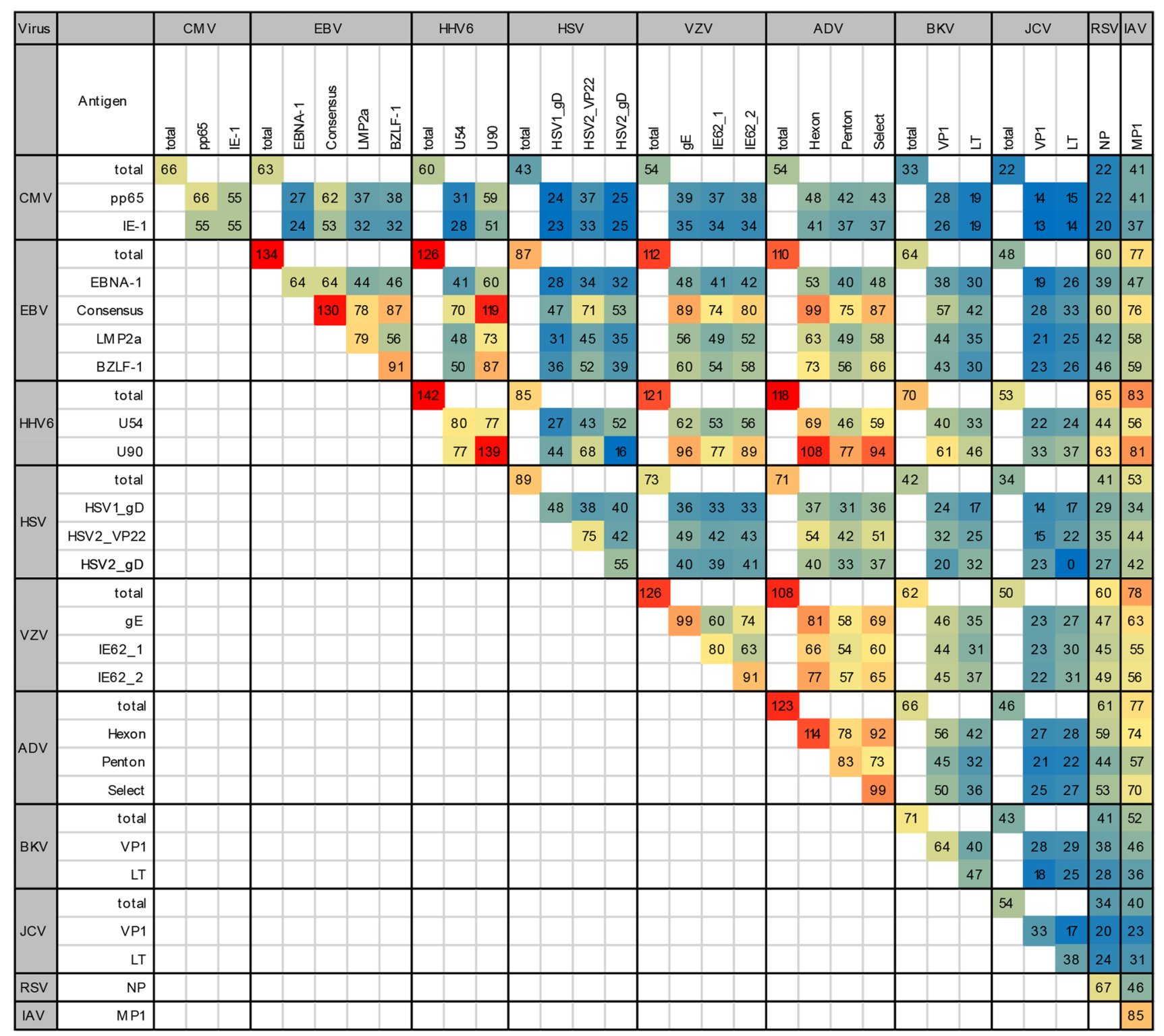

$\begin{array}{llllllllllllllll}0 & 10 & 20 & 30 & 40 & 50 & 60 & 70 & 80 & 90 & 100 & 110 & 120 & 130 & 142\end{array}$

Fig. 3 Relation between virus-specific T cells (VSTs). Number of donors with detectable VSTs against the indicated combinations of viral antigens. Where applicable, only seropositive donors were included (see also Fig. 1B). CMV cytomegalovirus, EBV Epstein-
Barr virus, HHV6 human herpesvirus 6, HSV herpes simplex virus, VZV varicella-zoster virus, ADV adenovirus, BKV BK polyomavirus, JCV JC polyomavirus, RSV respiratory syncytial virus, IAV influenza A virus cells to improve immunity in HSCT recipients with insufficient endogenous antiviral immunity. Conversely, SOT from seropositive donors to negative recipients is associated with an increased risk of primary viral infections in immunosuppressed SOT recipients. In this study, the discrepancies between ELISA-based CMV-IgG assay and immunoblotting as well as ELISpot assay for CMV indicated a false-positive rate of $13.1 \%$ for the CMV-IgG assay. As confirmed by other studies, standard serology tests might not be reliable enough for adoptive immunotherapy when no peptide-specific memory $\mathrm{T}$ cells are present $[44,46]$. Contrary to other studies [44, 47], we did not detect any CMV-specific T cells in seronegative donors, but the lack of detection might be due to the relatively short restimulation. Moreover, some donors with VSTs against a given virus were categorized as seronegative by ELISA, particularly for ADV, HSV, VZV, RSV, and IAV, which might be due to utilization of different, less concentrated surface antigens in ELISA compared to ELISpot. For instance, here, the utilized ADV-IgG assay covers ADV type 2 while ADV5_Hexon and ADV5_Penton 
peptide pools are derived from ADV type 5. Conversely, it might explain the lack of functional VSTs in some donors identified as ADV-seropositive. Similar circumstances presented for HSV, VZV, RSV, and IAV. Overall, majority of seropositive donors had the respective VSTs and their frequencies were significantly higher compared to seronegative donors. Furthermore, T-cell and antibody production is dependent on reinfection and recall immunization, which might not have occurred in these donors. However, one study using the HSV immunoblot assay suggests that exposure to HSV can induce HSV-specific cellular immunity without seroconversion [48]. This may also explain the observed discrepancy between HSV serostatus and the detection of HSV-specific T cells.

High frequencies of herpesvirus-specific $\mathrm{T}$ cells were detected in the present study, suggesting that viruses causing persistent infections are able to generate higher T-cell frequencies. Others have observed comparably high frequencies of VSTs for CMV [49] and EBV in healthy seropositive donors [50]. The ability of these viruses to achieve latency and frequently initiate productive replication cycles was shown in murine models [51]. This mechanism provides a continuous stimulus for the maintenance of VSTs. The positive correlation within the group of herpesviruses found in this study has been demonstrated previously [52-55]. It has been hypothesized that their high co-prevalence is associated with increased age or lower socioeconomic status [52]. Our study confirmed the association between age and seroprevalence, but did not assess socioeconomic factors. The majority of EBV-seropositive donors in the present study had EBV_Consensus-specific T cells. In contrast to the EBV-derived overlapping peptide pools covering the entire sequence of the respective protein, Consensus contains a mix of peptides derived from 13 lytic and latent EBV proteins, and covers 14 frequent HLA class I and II molecules. The use of overlapping peptide pools allows for detection of T-cell responses to multiple epitopes regardless of HLA type [56, 57], while the use of an antigen pool derived from various proteins with different HLA restrictions leads to a greater T-cell response with a higher range of clinically relevant VSTs due to its high antigenic diversity [58]. EBNA1-specific T cells are of utmost clinical importance since EBNA-1 plays numerous roles in EBV latency and is the only EBV protein expressed in all EBV-associated tumors [59, 60]. JC polyomavirus, which establishes persistent infections in the kidney and lymphoid organs, normally remains dormant but can reactivate in immunocompromised individuals where it can cause PML, a life-threatening infection of the brain [26-28, 61]. In this study, JCV yielded the lowest VST frequencies of all viruses tested. JCV-specific VST frequencies were reported to be low, but without sufficient evidence $[62,63]$. For IAV, a virus not typically causing long-term latent or persistent infections, we observed higher frequencies of antigen-specific $\mathrm{T}$ cells than for $\mathrm{BKV}$ and JCV. This finding contradicts the notion of a correlation between general viral latency and higher immune response. Herpesviruses are among the few viruses capable of true latency, i.e., persistence and reversibility, characterized by reactivation of expression of the entire viral genome under certain conditions [64]. The results of the present study suggest that true viral latency is associated with the generation of higher VST frequencies.

In this study, IAV and RSV were characterized by low VST frequencies. Both are RNA viruses infecting cells by directly releasing RNA into the cytoplasm of host cells [65]. Once inside, viral proteins can be replicated without transcribing viral DNA into RNA, unlike DNA viruses. Many RNA viruses do not elicit long-lasting immune protection after infection due to their innate immune evasion strategies and can cause a reoccurrence of symptoms. While IAV is able to elicit protective immunity, its genetic drift and shift usually lead to inadequate immune responses after reinfection. Because the affected immune response also impacts subsequent adaptive responses, viral innate immune evasion often undermines fully protective immunity [66].

Even though BKV belongs to the group of viruses with generally low VST frequencies [67], it is a major complication after kidney transplantation and therefore of high clinical relevance [17, 24, 68]. Despite high sequence homology between BKV and JCV, VST frequencies for JCV were lower compared to BKV. In line with previous studies, we observed a correlation between BKV-and JCV-reactive T cells $[69,70]$, implicating high potential of BKV-specific $T$ cells for treatment of both BKV- and JCV-associated diseases such as PML, where third-party BKV-specific T-cell transfer has shown promising results $[28,71,72]$.

The phenotypic structure of VSTs involved in different viral infections and reactivations varies due to differences in response patterns. In our study, $\mathrm{T}_{\mathrm{N}}$ frequencies were generally higher in individuals lacking antiviral $\mathrm{T}$ cells and in seronegative donors. It has been reported that while EBVand $\mathrm{HSV}$-specific $\mathrm{T}$ cells included higher ratios of $\mathrm{CD}^{+}$ $\mathrm{T}$ cells, $\mathrm{CD} 4^{+} \mathrm{T}$ cells were the dominant $\mathrm{T}$-cell subset in ADV, BKV, and VZV [73-77]. The importance of T-cell subsets varies depending on the virus and the associated disease and needs to be considered when evaluating patient immune status.

Our findings confirmed that antiviral immunity increases with age and that seroprevalence is higher among older individuals [78]. While age is associated with a highly differentiated T-cell repertoire because the cumulative number of contacts to viral agents increases over time [79], the process of immunosenescence leads to an age-related decrease in immune system activity, including T-cell function, despite higher effector T-cell frequencies [78, 80, 81]. Consequently, the decline in immune function is believed to increase the 
risk of viral infections and reactivations, leading to higher mortality rates among the elderly [40, 82]. Here, we determined the frequencies of IFN- $\gamma$-producing, functional, antiviral $\mathrm{T}$ cells, thereby—at least in part-accounting for the possible loss of immune function associated with aging. However, our cohort did not cover the entire age range. Characterization of the antiviral T-cell repertoire of older individuals requires the inclusion of additional factors like T-cell senescence, exhaustion, and additional effector molecules. However, as corroborated by other studies, our results indicate a correlation between age and VST frequency, possibly caused by more frequent and/or recurrent viral infections over time [53, 83, 84]. In contrast, younger individuals with no history of exposure to a broad variety of antigens often suffer from severe viral infections after transplantation due to the lack of endogenous antiviral T cells. In particular, EBV causes PTLD in many young patients after transplantation $[20,85]$. Due to their limited antiviral T-cell repertoire, further studies are needed to determine the VST frequencies for adjusting antiviral or immunosuppressive treatment strategies in young patients.

This study aimed to improve the clinical applicability of antiviral T-cell frequencies by characterizing $\mathrm{T}$ cells specific to clinically relevant viruses in terms of numbers as well as age and gender distribution in a great cohort of healthy donors. In line with previous studies, this study demonstrated that antiviral immunity increases with age. Furthermore, a positive correlation within herpesviruses was found. With exception of CMV_pp65, positive serology was not necessarily equivalent to detection of the respective VSTs. The findings of this study have important implications for the evaluation of T-cell mediated immunity and treatment decision-making to determine the need for antiviral treatment or reduction of immunosuppression. Together, this data will improve the outcome of immunocompromised patients and provide better comparability of currently used immunogenic stimulants regarding clinical outcome.

Supplementary Information The online version contains supplementary material available at https://doi.org/10.1007/s10875-021-01205-1.

Acknowledgements The authors would like to thank Dörthe Rokitta, Nicole Neumann, Sophie Meyer, and Bach Uy Vu for technical support.

Author Contribution Britta Maecker-Kolhoff and Britta Eiz-Vesper conceptualized and designed the study. Material preparation, data collection, and analysis were performed by Friederike Clara Schulze Lammers, Agnes Bonifacius, and Sabine Tischer-Zimmermann. Resources were contributed by Lilia Goudeva, Jörg Martens, Rainer Blasczyk, and Britta Eiz-Vesper. Clinical background was provided by Bernd Lepenies, Gunilla Einecke, Gernot Beutel, Thomas Skripuletz, Rita Beier, and Britta Maecker-Kolhoff. Statistical analyses were supported by Maria von Karpowitz. The first draft of the manuscript was written by Friederike Clara Schulze Lammers, Agnes Bonifacius, and Britta Eiz-Vesper and all authors commented on previous versions of the manuscript. All authors read and approved the final manuscript.
Funding Open Access funding enabled and organized by Projekt DEAL. This work was supported by the German Research Foundation (DFG) research unit 2830 "Advanced Concepts in Cellular Immune Control of Cytomegalovirus" to FCSL, SFB900/B11 [project ID $158989968]$ to AB and the Immunotherapy Foundation.

Data availability All data generated in this study are provided in the main manuscript and supplemental information.

Code Availability Not applicable.

\section{Declarations}

Ethics Approval All procedures performed in this study were in accordance with the ethical standards of the institutional committee. The study was approved by the Hannover Medical School ethics committee (vote 3639-2017).

Consent to Participate Written informed consent was obtained from all participants included in the study.

Consent for Publication Written informed consent was obtained from all participants included in the study. No identifying information from individual participants is included.

Conflict of Interest The authors declare no competing interests.

Open Access This article is licensed under a Creative Commons Attribution 4.0 International License, which permits use, sharing, adaptation, distribution and reproduction in any medium or format, as long as you give appropriate credit to the original author(s) and the source, provide a link to the Creative Commons licence, and indicate if changes were made. The images or other third party material in this article are included in the article's Creative Commons licence, unless indicated otherwise in a credit line to the material. If material is not included in the article's Creative Commons licence and your intended use is not permitted by statutory regulation or exceeds the permitted use, you will need to obtain permission directly from the copyright holder. To view a copy of this licence, visit http://creativecommons.org/licenses/by/4.0/.

\section{References}

1. Duver F, Weissbrich B, Eyrich M, Wolfl M, Schlegel PG, Wiegering V. Viral reactivations following hematopoietic stem cell transplantation in pediatric patients - a single center 11-year analysis. PLoS One. 2020;15(2):e0228451.

2. Kaeuferle T, Krauss R, Blaeschke F, Willier S, Feuchtinger T. Strategies of adoptive $\mathrm{T}$-cell transfer to treat refractory viral infections post allogeneic stem cell transplantation. J Hematol Oncol. 2019;12(1):13.

3. Styczynski J, Tridello G, Koster L, Iacobelli S, van Biezen A, van der Werf S, et al. Death after hematopoietic stem cell transplantation: changes over calendar year time, infections and associated factors. Bone Marrow Transplant. 2020;55(1):126-36.

4. Riella LV. Understanding the causes of mortality post-transplantation - there is more than meets the eye. J Bras Nefrol. 2018;40(2):102-4.

5. Liliya I. - Viral Diseases in Transplant and Immunocompromised Patients N2 - This book is a continuation of the efforts of InTech to expand the scientific know-how in the field of immunopathology and bring valuable updated information to medical 
professionals and researchers. It consists of chapters related to various approaches to investigate the unique role of the immune system in response to different clinical disorders. The international team of authors is the bonus of the book, reflecting the rapid development of immunology and new achievements in medical science. We firmly hope that the book will be an excellent manual and guideline for people dealing with biology, microbiology, immunology, virology, pharmacology, general and dental medicine, and health care, from students and postdocs to high-level specialists and university professors.- Ch. 6.

6. Bula-Rudas FJ, Windle ML, Domachowske J, Steele RW, Brook I, Chatterjee A, et al. Infections in the immunocompromised host Medscape. J Med. 2020

7. Keller MD, Bollard CM. Virus-specific T-cell therapies for patients with primary immune deficiency. Blood. 2020;135(9):620-8.

8. Leen AM, Tripic T, Rooney CM. Challenges of T cell therapies for virus-associated diseases after hematopoietic stem cell transplantation. Expert Opin Biol Ther. 2010;10(3):337-51.

9. Meidani M, Naeini AE, Rostami M, Sherkat R, Tayeri K. Immunocompromised patients: Review of the most common infections happened in 446 hospitalized patients. J Res Med Sci. 2014;19(Suppl 1):S71-3.

10. Englund J, Feuchtinger T, Ljungman P. Viral infections in immunocompromised patients. Biol Blood Marrow Transplant. 2011;17(1 Suppl):S2-5.

11. Styczynski J. Who is the patient at risk of CMV recurrence: a review of the current scientific evidence with a focus on hematopoietic cell transplantation. Infect Dis Ther. 2018;7(1):1-16.

12. Fishman JA. Infection in organ transplantation. Am J Transplant. 2017;17(4):856-79.

13. Bollard CM, Heslop HE. T cells for viral infections after allogeneic hematopoietic stem cell transplant. Blood. 2016;127(26):3331-40.

14. Sehrawat S, Kumar D, Rouse BT. Herpesviruses: harmonious pathogens but relevant cofactors in other diseases? Front Cell Infect Microbiol. 2018;8:177.

15. George B, Pati N, Gilroy N, Ratnamohan M, Huang G, Kerridge I, et al. Pre-transplant cytomegalovirus (CMV) serostatus remains the most important determinant of $\mathrm{CMV}$ reactivation after allogeneic hematopoietic stem cell transplantation in the era of surveillance and preemptive therapy. Transpl Infect Dis. 2010;12(4):322-9.

16. Ottaviano G, Chiesa R, Feuchtinger T, Vickers MA, Dickinson A, Gennery AR, et al. Adoptive T cell therapy strategies for viral infections in patients receiving haematopoietic stem cell transplantation. Cells. 2019;8(1)

17. Hill JA, Mayer BT, Xie H, Leisenring WM, Huang ML, StevensAyers T, et al. The cumulative burden of double-stranded DNA virus detection after allogeneic HCT is associated with increased mortality. Blood. 2017;129(16):2316-25.

18. Janeczko M, Mielcarek M, Rybka B, Ryczan-Krawczyk R, Noworolska-Sauren D, Kalwak K. Immune recovery and the risk of $\mathrm{CMV} / \mathrm{EBV}$ reactivation in children post allogeneic haematopoietic stem cell transplantation. Cent Eur J Immunol. 2016;41(3):287-96.

19. Ahmad I, Cau NV, Kwan J, Maaroufi Y, Meuleman N, Aoun M, et al. Preemptive management of Epstein-Barr virus reactivation after hematopoietic stem-cell transplantation. Transplantation. 2009;87(8):1240-5.

20. Francis A, Johnson DW, Teixeira-Pinto A, Craig JC, Wong G. Incidence and predictors of post-transplant lymphoproliferative disease after kidney transplantation during adulthood and childhood: a registry study. Nephrol Dial Transplant. 2018;33(5):881-9.

21. Lion T. Adenovirus infections in immunocompetent and immunocompromised patients. Clin Microbiol Rev. 2014;27(3):441-62.
22. Ogata M, Satou T, Kadota J-I, Saito N, Yoshida T, Okumura $\mathrm{H}$, et al. Human herpesvirus 6 (HHV-6) reactivation and HHV-6 encephalitis after allogeneic hematopoietic cell transplantation: a multicenter, prospective study. Clin Infect Dis. 2013;57(5):671-81.

23. Taneja A, Chewning JH, Saad A. Viral infections after allogeneic hematopoietic stem cell transplant. Adv Cell Gene Ther. 2019;2(2):e43.

24. Demey B, Tinez C, Francois C, Helle F, Choukroun G, Duverlie $\mathrm{G}$, et al. Risk factors for BK virus viremia and nephropathy after kidney transplantation: a systematic review. J Clin Virol. 2018;109:6-12.

25. Per Ljungman DS, Michael Boeckh. Transplant Infections: Fourth Edition. 2016

26. Shitrit D, Lev N, Bar-Gil-Shitrit A, Kramer MR. Progressive multifocal leukoencephalopathy in transplant recipients. Transpl Int. 2005;17(11):658-65.

27. Ferenczy MW, Marshall LJ, Nelson CD, Atwood WJ, Nath A, Khalili K, et al. Molecular biology, epidemiology, and pathogenesis of progressive multifocal leukoencephalopathy, the JC virusinduced demyelinating disease of the human brain. Clin Microbiol Rev. 2012;25(3):471-506.

28. Muftuoglu M, Olson A, Marin D, Ahmed S, Mulanovich V, Tummala S, et al. Allogeneic BK virus-specific T cells for progressive multifocal leukoencephalopathy. N Engl J Med. 2018;379(15):1443-51.

29. Sorel O, Messaoudi I. Varicella virus-host interactions during latency and reactivation: lessons from simian varicella virus. Front Microbiol. 2018;9:3170.

30. Meyding-Lamadé U, Strank C. Herpesvirus infections of the central nervous system in immunocompromised patients. Ther Adv Neurol Disord. 2012;5(5):279-96.

31. Gabutti G, De Motoli F, Sandri F, Toffoletto MV, Stefanati A. Viral respiratory infections in hematological patients. Infect Dis Ther. 2020;1-16

32. Neemann K, Freifeld A. Respiratory syncytial virus in hematopoietic stem cell transplantation and solid-organ transplantation. Curr Infect Dis Rep. 2015;17(7):490.

33. Elste J, Kaltenbach D, Patel VR, Nguyen MT, Sharthiya H, Tandon R, et al. Inhibition of human cytomegalovirus entry into host cells through a pleiotropic small molecule. Int J Mol Sci. 2020;21(5).

34 Irwin KK, Renzette N, Kowalik TF, Jensen JD. Antiviral drug resistance as an adaptive process. Virus Evol. 2016;2(1):vew014.

35. Lohmann L, Janoschka C, Schulte-Mecklenbeck A, Klinsing S, Kirstein L, Hanning U, et al. Immune cell profiling during switching from natalizumab to fingolimod reveals differential effects on systemic immune-regulatory networks and on trafficking of non-T cell populations into the cerebrospinal fluid-results from the ToFingo Successor Study. Front Immunol. 2018;9:1560.

36 Worel N, Pfistershammer K, Pickl W, Heinz M, Schlager M, Pribitzer B, et al. Influence of CD27- CD28- T-cells on the therapeutic outcome in adult patients with relapsed or refractory diffuse large B-cell lymphoma after CART-infusion. Blood. 2019;134(Supplement 1): 1935 .

37. Ciáurriz M, Zabalza A, Beloki L, Mansilla C, Pérez-Valderrama $\mathrm{E}$, Lachén $\mathrm{M}$, et al. The immune response to cytomegalovirus in allogeneic hematopoietic stem cell transplant recipients. Cell Mol Life Sci. 2015;72(21):4049-62.

38. Barrett AJ, Prockop S, Bollard CM. Virus-specific T cells: broadening applicability. Biol Blood Marrow Transplant. 2018;24(1):13-8.

39. Houghtelin A, Bollard CM. Virus-specific T cells for the immunocompromised patient. Front Immunol. 2017;8:1272. 
40. Lindau P, Mukherjee R, Gutschow MV, Vignali M, Warren EH, Riddell SR, et al. Cytomegalovirus Exposure in the Elderly Does Not Reduce CD8 T Cell Repertoire Diversity. J Immunol. 2019;202(2):476-83.

41. Di Benedetto S, Derhovanessian E, Steinhagen-Thiessen E, Goldeck D, Müller L, Pawelec G. Impact of age, sex and CMVinfection on peripheral $\mathrm{T}$ cell phenotypes: results from the Berlin BASE-II Study. Biogerontology. 2015;16(5):631-43.

42. Liu L, Liu Q, Feng S. Management of Epstein-Barr virus-related post-transplant lymphoproliferative disorder after allogeneic hematopoietic stem cell transplantation. Therapeut Adv Hematol. 2020;11.

43. Ruderfer D, Au J, Seth A, Naik S, Bocchini CE. BK Virus Epidemiology, Risk factors and outcomes: a retrospective analysis of hematopoietic stem cell transplant patients at Texas Children's Hospital. Open Forum Infect Dis. 2016;3(suppl_1).

44. Sukdolak C, Tischer S, Dieks D, Figueiredo C, Goudeva L, Heuft HG, et al. CMV-, EBV- and ADV-specific T cell immunity: screening and monitoring of potential third-party donors to improve post-transplantation outcome. Biol Blood Marrow Transplant. 2013;19(10):1480-92.

45. Mangare C, Tischer-Zimmermann S, Riese SB, Dragon AC, Prinz I, Blasczyk R, et al. Robust identification of suitable T-cell subsets for personalized CMV-specific T-cell immunotherapy using CD45RA and CD62L microbeads. Int J Mol Sci. 2019;20(6).

46. Navarro D, Fernandez-Ruiz M, Aguado JM, Sandonis V, Perez-Romero P. Going beyond serology for stratifying the risk of CMV infection in transplant recipients. Rev Med Virol. 2019;29(1):e2017.

47. Loeth N, Assing K, Madsen HO, Vindelov L, Buus S, Stryhn A. Humoral and cellular CMV responses in healthy donors; identification of a frequent population of CMV-specific, CD4+ T cells in seronegative donors. PLoS One. 2012;7(2):e31420.

48. Posavad CM, Remington M, Mueller DE, Zhao L, Magaret AS, Wald A, et al. Detailed characterization of $\mathrm{T}$ cell responses to herpes simplex virus-2 in immune seronegative persons. J Immunol. 2010;184(6):3250-9.

49. Gillespie GM, Wills MR, Appay V, O'Callaghan C, Murphy M, Smith N, et al. Functional heterogeneity and high frequencies of cytomegalovirus-specific CD8(+) T lymphocytes in healthy seropositive donors. J Virol. 2000;74(17):8140-50.

50. Long HM, Meckiff BJ, Taylor GS. The T-cell Response to Epstein-Barr Virus-New Tricks From an Old Dog. Front Immunol. 2019;10:2193.

51. Sester M, Sester U, Gartner B, Kubuschok B, Girndt M, Meyerhans A, et al. Sustained high frequencies of specific CD4 T cells restricted to a single persistent virus. J Virol. 2002;76(8):3748-55.

52. Delaney AS, Thomas W, Balfour HH Jr. Coprevalence of Epstein-Barr Virus, Cytomegalovirus, and Herpes Simplex Virus Type-1 Antibodies Among United States Children and Factors Associated With Their Acquisition. J Pediatric Infect Dis Soc. 2014;4(4):323-9.

53 Winter JR, Jackson C, Lewis JE, Taylor GS, Thomas OG, Stagg HR. Predictors of Epstein-Barr virus serostatus and implications for vaccine policy: A systematic review of the literature. J Glob Health. 2020;10(1):010404.

54. van den Heuvel D, Jansen MAE, Dik WA, Bouallouch-Charif H, Zhao D, van Kester KAM, et al. Cytomegalovirus- and EpsteinBarr Virus-Induced T-Cell Expansions in Young Children Do Not Impair Naive T-cell Populations or Vaccination Responses: The Generation R Study. J Infect Dis. 2015;213(2):233-42.

55. Sundqvist E, Bergstrom T, Daialhosein H, Nystrom M, Sundstrom $\mathrm{P}$, Hillert $\mathrm{J}$, et al. Cytomegalovirus seropositivity is negatively associated with multiple sclerosis. Mult Scler. 2014;20(2):165-73.
56. Maecker HT, Dunn HS, Suni MA, Khatamzas E, Pitcher CJ, Bunde T, et al. Use of overlapping peptide mixtures as antigens for cytokine flow cytometry. J Immunol Methods. 2001;255(1):27-40.

57. Körber N, Behrends U, Protzer U, Bauer T. Evaluation of T-activated proteins as recall antigens to monitor Epstein-Barr virus and human cytomegalovirus-specific $\mathrm{T}$ cells in a clinical trial setting. J Transl Med. 2020;18(1):242.

58. Moosmann A, Bigalke I, Tischer J, Schirrmann L, Kasten J, Tippmer S, et al. Effective and long-term control of EBV PTLD after transfer of peptide-selected T cells. Blood. 2010;115(14):2960-70.

59. Frappier L. The Epstein-Barr Virus EBNA1 Protein. Scientifica (Cairo). 2012;2012:438204

60. Sivachandran N, Wang X, Frappier L. Functions of the EpsteinBarr virus EBNA1 protein in viral reactivation and lytic infection. J Virol. 2012;86(11):6146-58.

61. Assetta B, Atwood WJ. The biology of JC polyomavirus. Biol Chem. 2017;398(8):839-55.

62. Du Pasquier RA, Schmitz JE, Jean-Jacques J, Zheng Y, Gordon J, Khalili K, et al. Detection of JC virus-specific cytotoxic T lymphocytes in healthy individuals. J Virol. 2004;78(18):10206-10.

63. Lima MA, Marzocchetti A, Autissier P, Tompkins T, Chen Y, Gordon J, et al. Frequency and phenotype of JC virus-specific CD8+ $\mathrm{T}$ lymphocytes in the peripheral blood of patients with progressive multifocal leukoencephalopathy. J Virol. 2007;81(7):3361-8.

64. Speck SH, Ganem D. Viral latency and its regulation: lessons from the gamma-herpesviruses. Cell Host Microbe. 2010;8(1):100-15.

65. Kaufman HL, Kohlhapp FJ, Zloza A. Oncolytic viruses: a new class of immunotherapy drugs. Nat Rev Drug Discov. 2015;14(9):642-62.

66. Kikkert M. Innate Immune Evasion by Human Respiratory RNA Viruses. J Innate Immun. 2020;12(1):4-20.

67. Cioni M, Leboeuf C, Comoli P, Ginevri F, Hirsch HH. Characterization of Immunodominant BK Polyomavirus 9mer Epitope T Cell Responses. Am J Transplant. 2016;16(4):1193-206.

68. Pello OM, Innes AJ, Bradshaw A, Finn SA, Uddin S, Bray E, et al. BKV-specific $\mathrm{T}$ cells in the treatment of severe refractory haemorrhagic cystitis after HLA-haploidentical haematopoietic cell transplantation. Eur J Haematol. 2017;98(6):632-4.

69. Mani J, Wang L, Huckelhoven AG, Schmitt A, Gedvilaite A, Jin $\mathrm{N}$, et al. Definition and characterization of novel HLA-*A02restricted CD8+ T cell epitopes derived from JCV polyomavirus with clinical relevance. Oncotarget. 2017;8(2):2485-500.

70. Ramos E, Drachenberg CB, Wali R, Hirsch HH. The decade of polyomavirus BK-associated nephropathy: state of affairs. Transplantation. 2009;87(5):621-30.

71. Hopfner F, Mohn N, Eiz-Vesper B, Maecker-Kolhoff B, Gottlieb J, Blasczyk R, et al. Allogeneic BK Virus-Specific T-Cell Treatment in 2 Patients With Progressive Multifocal Leukoencephalopathy. Neurol Neuroimmunol Neuroinflamm. 2021;8(4).

72. Steinhardt MJ, Wiercinska E, Pham M, Grigoleit GU, Mazzoni A, Da-Via M, et al. Progressive multifocal leukoencephalopathy in a patient post allo-HCT successfully treated with JC virus specific donor lymphocytes. J Transl Med. 2020;18(1):177.

73. Binggeli S, Egli A, Schaub S, Binet I, Mayr M, Steiger J, et al. Polyomavirus BK-Specific Cellular Immune Response to VP1 and Large T-Antigen in Kidney Transplant Recipients. Am J Transplant. 2007;7(5):1131-9.

74. Meckiff BJ, Ladell K, McLaren JE, Ryan GB, Leese AM, James EA, et al. Primary EBV Infection Induces an Acute Wave of Activated Antigen-Specific Cytotoxic CD $4<\sup >+</$ sup $>$ T Cells. J Immunol. 2019;203(5):1276-87.

75. Soerens AG, Da Costa A, Lund JM. Regulatory T cells are essential to promote proper CD4 T-cell priming upon mucosal infection. Mucosal Immunol. 2016;9(6):1395-406.

76. Feuchtinger T, Lücke J, Hamprecht K, Richard C, Handgretinger $\mathrm{R}$, Schumm M, et al. Detection of adenovirus-specific T cells 
in children with adenovirus infection after allogeneic stem cell transplantation. Br J Haematol. 2005;128(4):503-9.

77. Haredy AM, Takei M, Iwamoto S-I, Ohno M, Kosaka M, Hirota $\mathrm{K}$, et al. Quantification of a cell-mediated immune response against varicella zoster virus by assessing responder CD4high memory cell proliferation in activated whole blood cultures. Vaccine. 2019;37(36):5225-32.

78. Pawelec G, McElhaney JE, Aiello AE, Derhovanessian E. The impact of CMV infection on survival in older humans. Curr Opin Immunol. 2012;24(4):507-11.

79. Pangrazzi L, Weinberger B. T cells, aging and senescence. Exp Gerontol. 2020;134:110887.

80. Aiello A, Farzaneh F, Candore G, Caruso C, Davinelli S, Gambino $\mathrm{CM}$, et al. Immunosenescence and Its Hallmarks: How to Oppose Aging Strategically? A Review of Potential Options for Therapeutic Intervention. Front Immunol. 2019;10:2247.

81. Ventura MT, Casciaro M, Gangemi S, Buquicchio R. Immunosenescence in aging: between immune cells depletion and cytokines up-regulation. Clin Mol Allergy. 2017;15:21.

82. Oh SJ, Lee JK, Shin OS. Aging and the Immune System: the Impact of Immunosenescence on Viral Infection, Immunity and Vaccine Immunogenicity. Immune Netw. 2019;19(6):e37.
83. van den Berg SPH, Pardieck IN, Lanfermeijer J, Sauce D, Klenerman $\mathrm{P}$, van Baarle $\mathrm{D}$, et al. The hallmarks of CMVspecific CD8 T-cell differentiation. Med Microbiol Immunol. 2019;208(3-4):365-73.

84. Thomasini RL, Pereira DS, Pereira FSM, Mateo EC, Mota TN, Guimaraes GG, et al. Aged-associated cytomegalovirus and Epstein-Barr virus reactivation and cytomegalovirus relationship with the frailty syndrome in older women. PLoS One. 2017;12(7):e0180841.

85 Watson C, Xu H, Forsythe A, Garib SA, Barlev A. Younger Patients Are Impacted By Post-Transplant Lymphoproliferative Disorder: Findings from a Systematic Literature Review of RealWorld Evidence. Blood. 2018;132(Supplement 1):5841.

Publisher's Note Springer Nature remains neutral with regard to jurisdictional claims in published maps and institutional affiliations. 